\title{
Human Resource Policy: A Strategic Research for Sustainable Tourism Outcomes in Karimunjawa Tourism Village
}

\author{
Budi Setiawan $^{1 *}$, Agus Budi Santoso ${ }^{1}$, Sugeng Eko Putro Widoyoko ${ }^{2}$, \\ Didik Widiyantono ${ }^{3}$
}

\author{
${ }^{1}$ Department of Social Scence, Universitas Muhammadiyah Purworejo, Purworejo, Indonesia \\ ${ }^{2}$ Department of Education, Universitas Muhammadiyah Purworejo, Purworejo, Indonesia \\ ${ }^{3}$ Department of Agriculture, Universitas Muhammadiyah Purworejo, Purworejo, Indonesia \\ *Corresponding author.Email: budi.setiawan@umpwr.ac.id
}

\begin{abstract}
A combination of appropriate government policies, laws, and regulations, with the development of human resources (HRD), contributes to the long-term sustainability of tourism destinations. This research, therefore, determines the role of government policy in HRD as a contributor to tourism development in Karimunjawa village. Data were collected from local community representatives, educators, and by using questionnaires. The result showed that governments had ignored HRD policies while making developmental plan for tourism, which has a detrimental impact on long-term sustainability.
\end{abstract}

Keywords: government policy, sustainable tourism, human resources development, Karimunjawa

\section{INTRODUCTION}

Tourism is one of the biggest and rapidly evolving industries in the world, with great potentials for the socioeconomic development of rural areas. Therefore, it generates a unique life and culture for the surrounding inhabitants affected by a decrease in traditional agricultural activities [1]. Tourism has become a popular development strategy applied in many regions, in order to improve their local economy and eradicate poverty [2]. Due to this reason, its realization has been created as a policy in developed and developing nations [3][4][5] [6][7].

In addition, due to the various developmental challenges faced by these villages, they tend to solely depend on tourism to boost their economy [8]. Hawkins defined tourism as a goose that grows golden and destroys its eggs,' [9]. This definition, is in line with the core assets of human resources, is considered insufficient in many development plans [10] [11]. Nevertheless, resource-based theories stated that the quality of human resources (HRD) provides a significant advantage [12]. For example, Wong et al. [13] stated that employees need to be highly skilled and knowledgeable in order to contribute to the regional competitiveness of ASEAN tourism.

In Indonesia, government policies are used to foster innovative and competent professionals in accordance with tourism destinations. Despite this appeal, researches focusing on HRD experiences are lacking. In addition, academic debates on government involvement in HR policies are also limited in developing countries [14].
Furthermore, there are numerous challenges pertaining to human resources that are faced in the operation of the tourism industry such as the features of the labor market, recruitment, retention, turnover, training, career development, low-income rates, abnormal working hours and conditions [15]. HRD tends to maintain quality service, loyalty, customer satisfaction, improve industry performance, and achieve competitive goals [16]. This is because many poor-quality tourism areas are due to the lack of on-the-job training, and this leads to reduced competitiveness and inadequate service [17], [18].

One of the leading indicators of the social sustainability in tourism is the number of workers in managerial positions, as well as the availability of training, and education to civil servants [19]. Furthermore, indirect employment is created by industry operators that purchase locally sourced and manufactured materials to ensure the economic sustainability of the area [19]. In addition, well-educated expatriates tend to contribute immensely to the improvement of quality service, and also create an unsustainable situation for tourist destinations. For instance, absolute dependence on expatriates, leads to increased leakage of tourism revenues [11].

The government's HRD policies variation, are dependent on the local context, and conditions of the global labor market. Subsequently, it requires a systematic approach in accordance with estimating the needs of the workers, demand for skills and education as well as the involvement of relevant stakeholders [19], [20]. In addition to developing the skills, policies need to include training, procedures for national certification, education standards, and development of tourism educators [21]. In developing countries, the private sectors often find it difficult to handle all HRD responsibilities, therefore, the governments' expertise are often required [22], [23].

Therefore, the key factors used to achieve sustainable outcomes are dependent on the government and industry's commitments to maintain and develop tourism education 
and skills. However, complexity arose due to the numerous definitions of HRD [24]. Weinberger stated 18 different meanings applied by various academicians [25]. The core themes discovered are learning, improved performance, training, organizational, and career development. Although HRD has no specific definition, the generally accepted meaning is that it is the development of expertise to enhance individual skills, teamwork, processes, and organizational performance [26]. Due to its historical roots in education and employment, HRD, therefore, represents the learning and orientation of both individuals and organizations [27]. Conversely, some academics stated that education and training are dissimilar. Some others have observed that theoretical knowledge and instruction evolved independently, although in practice, both are closely intertwined [28], [29]. In this context, HRD consist of the process of delivering knowledge (education) and instruction (training) in order to produce people with an agreed standard of proficiency to take up the necessary responsibilities. For the purpose of this research, it includes education and training on tourism. Therefore, the HRD policy is a deliberate action developed by the government to train people on the required skills needed for employment, and to make contribution in the decisionmaking processes. A high level of investment in tourism education quickly gained national development in most countries [30].

Due to the importance of human resources, this research aims to explore the role of government policy in the sustainable development of tourism. The sample consists of people living in Karimunjawa village, which is a rural community on the small islands of the Java Sea.

This article is composed of the following, a description of the background, literature review, and characteristics of the research area, the methodology used is explained. Furthermore, the results were analyzed, and finally, a conclusion was drawn.

\section{RESEARCH METHOD}

\subsection{Research Area}

Karimunjawa was the sample area used to carry out this research. It is a sub-district in Jepara regency, Central Java and located at $83 \mathrm{~km}$ north-west of Jepara, at a longitude of $5^{\circ} 40^{\prime} 39^{\prime \prime}-5^{\circ} 55^{\prime} 00^{\prime \prime}$ and 100 $101^{\prime} 15^{\prime \prime}$ in the East, at a height of 0-605 m asl. It has an area of 169,800 ha, which consists of 7,120 ha of land and162, 680 ha of marine.

\subsection{Methods}

The case research method was adopted to explore how the community utilizes their knowledge, experience and efforts, to improve their livelihood in the socio-economic environment. Furthermore, the purposive and snowballing methods were used to conduct in-depth interviews on several key persons that represent the community. The relevant stakeholders identified are the managers, educators, and local community representatives. Various data collection techniques were used to obtain data such as the semi-structured face-to-face interviews on twenty-eight tourism educators, semi-structured focus groups on eight local community representatives and mailing survey questionnaires to managers of the tourism industry $(n=74)$. This research is limited to the use of managers while ignoring other employees working in the industry. The authors acknowledged that this aspect needs to be discussed in subsequent researches. In addition, the snowball and the purposive non-probability cluster sampling were employed to select the tourism educator and the local community representatives, respectively.

\subsection{Data Analysis Method}

The manual coding technique and inductive approach were used to analyze the data. This process started by categorizing the transformation indicators associated with the knowledge, experiences, and efforts utilized by the community to minimize their vulnerability to tourism development.

Furthermore, the interviews data were coded, compiled, and were further analyzed by using the content analysis principle [31] [32]. Therefore, its content is analyzed as a group rather than individually, with the identification process, focus group, and discussions encoded as FG, educator interviews were associated with INT.

The codes are sorted according to their themes, with dependence on their correlation with each other. Focus group discussions, in-depth interviews, and industry surveys tend to allow comparison, and an interpretation of the phenomenon under study.

\section{RESULTS AND DISCUSSION}

\subsection{The Impact of Tourism on People's Livelihood}

Tourism is one of the potentials for development on the Island. As the largest industry, it is a component of economic development in numerous countries with the ability to yield foreign exchange, increase tax revenues, create new employment opportunities, and attract international investments. There is a significant increase in the number of foreign and domestic tourists to the Island since 2007. In 2015 a total of 7,579 foreign tourists, and 84,536 domestic visitors, visited the region, however, there is a continual increase compared to the preceding years (Tourism Information Center of Jepara, 2014). The number of foreign and domestic tourists increased from $158 \%$ and $166 \%$ in 2015, as shown in Figure 1. Therefore, Karimunjawa has the potential for tourism development, with the increase due to the introduction of a ferryboat navigating through Kendal and Jepara seaports. 




Figure 1 Graphic of visits to Karimunjawa

There is a total of 38 domestic and foreign tourists' destinations in Karimunjawa. However, the Menjangan Island, Shark Pond, few coasts, namely Barakuda, Nirwana, Batu Topeng, Ujung Gelam, Batu Putih, Kemloko, and Batu Lawang are the most visited areas. This community also offers, tourism related to religion, such as visits to the cemeteries of past pious leaders (e.g., Sayyid Kambang, Sunan Nyamplungan, and Sayyid Abdullah). In addition, the Barikan and Sail annual events, also serve as tourist attractions. Karimunjawa village is a frequently visited region, with a percentage rate of $69 \%$ as shown in Figure 2.

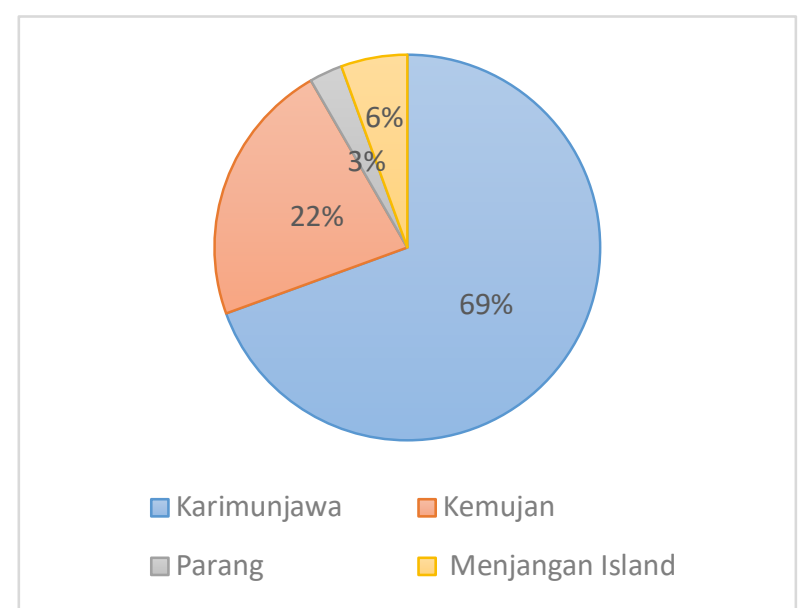

Figure 2 Distribution of Destinations on Karimunjawa Island

\subsection{The Impact of Tourism on Household Capital and Activities}

The Assessment of tourism in the community has a positive and negative impact. Tourism is a new sphere for the people of Karimunjawa and has considerable potential risk. The majority of the people regard it as an opportunity for additional activities that tend to be combined with the existing means of livelihood, not as a substitute. Therefore, the issue of how it supplements or conflicts with existing activities have always emerged during numerous interviews. One of the best ways in which tourism supports other activities is to strengthen the productive capacity of households, such as improved skills and provision of cash for investment. Cash appeals to the people of the community, and they usually invest in boats, motorcycles, and instruments for communication.

Tourism tends to be incompatible with the existing activities in terms of reduced access to natural resources in accordance with the time spent. Specifically, it conflicts with activities such as fishing, breeding livestock, and plant production, which are the major occupations of the people in the villages. It also leads to the loss of plant products, which is the major concern of poor households in Karimunjawa, particularly the women that are reliant on harvests of various natural resources for foodstuffs, drugs, and fuel. The amount of time taken up by tourism is quite significant. For example, fishermen engaged in tourism prefer to serve tourists because they are attracted by the payment, which is in cash, and there is a lesser degree of risk. The increase in the number of visitors discourages fishermen from going to the sea, at weekends and even on weekdays to serve the tourists. Table 3 summarizes several ways in which tourism tends to negatively and positively affect a range of rural activities in Karimunjawa. It does not show the differential impacts between the various regions and groups of residents. However, there is high variability.

\subsection{Human Resources Development Policy at Karimunjawa}

The stakeholder's examination, showed that $64 \%$ of tourism educators $(\mathrm{n}=18)$ and $88 \%$ of the local community representatives $(n=7)$ reported that the government has not implemented a tourism-related HRD policy. This is in line with the views of $64 \%$ of the managers $(n=47)$, that noted that the lack of government policies poses challenges to sustainable industrial development as shown in Table 2. Conversely, $30 \%$ of the surveyed managers surveyed, $(n=$ 22) reported that the government had an effective HRD strategy for the industry.

According to the local community representatives, 'the government does not possess adequate human resources and development policies' (FG07). In addition, no attention is paid to tourism education as well as the development of human resources' (FG03). This is supported by the educators that that support the fact that the government has no policy regarding the development of human resource ' (INT11).

Furthermore, approximately $65 \%$ of the local community representatives $(n=5)$ reported that the government policy is influenced by the owners of the tourism industry. According to them, the HRD related actions are not implemented due to the higher forces that influence the government's decisions (FG07). However, only two respondents $(7 \%)$ were able to identify the influence of industry elites on government policy.

The tourism industry is an integral part of the ruling elite and this has made the government reliant in imposing laws that limit the expatriates, and the implementation of the Employment Act and taxation. In addition, this is termed an illegal alliance between the government and industry (INT11). According to the tourism educators and local community representatives' the government has failed to support the tourism industry and national human resources 
with insufficient number of doctors, nurses, staff, and accountant specialized in the field (INT28)

There are no government regulations to recognize the locals and appreciate their experiences, without developing the community. According to analysis, whenever the government executes a project, the benefits are felt after 30 years. However, the common question asked is the role of the local government (FG04). The theme further expressed the lack of strategic government directives on human resources related to tourism. In addition, an educator stated that they are in a situation where they do not know where they are going because there is no strategic direction' (INT 19). Members of the local community also criticize this deficiency. The government tends to do everything to ease the work abroad however, they have no plans to develop the local communities (FG03).

The emergence of this research is the lack of stakeholders' involvement in the development of human resources policies. This has been observed to be the main loophole at all stages of planning. During decision-making, the members, committees, and councils do not understand the consequences of the actions they take. They are only given a pamphlet of two or three short pages after which the chairperson delivers a 5 minutes brief proposal, policies, and plans. There is no industry representation (INT15).

\subsection{Discussion}

This research shows that although the Indonesian government aims at expanding the tourism industry, it does not have adequate HRD needs such as knowledge, skills and workers from the local communities. This is due to the poor policy and structure of the industry without proper planning (FG03). In addition, further studies reported that the tourism industry has been in existence for a quarter of a century, with an improvement in the local HRD due to lack of development by the government. Therefore, industrial managers, are faced with lots of challenge towards its sustainability. This is evident in certain cases, conversely tourism development policies that allow unlimited expansion of the industry do not only have a negative impact on the destination environment, and it also adds pressure to the human resources. In addition, inadequate skills and education also leads to poor service delivery, thereby affecting the purpose of the industry.

The people of Karimunjawa lacked the required skills and knowledge demanded by the industry, therefore, they do not benefit from its proceeds. Apart from direct employment, the effects of tourism multiplier remain low on local communities due to the establishment of sub-companies by resort operators. In addition, this situation also occurred due to the poor financial state of the majority of the local population. This leads to a situation where a large amount of tourism wealth is concentrated in the hands of several local elites and foreign investors.

Furthermore, because of the government's policy of alienating tourism from local communities, the people now have the perception that it is a 'bad industry.' Operators are not able to attract local residents that are interested in pursuing a career in this industry due to this resort. Therefore, a high dependence on expatriates is required in order to meet the demand for skilled labor, which leads to a high leak of tourism revenues, economic, socio-economic and cultural issues in Karimunjawa.

The development of appropriate HR policies, poor strategies, and commitment to human rights tend to influence these policies. However, despite work-related legal changes, a good number of industrial operators have failed to comply with this law. Therefore, employers treat their workers inappropriately with the non-payment of wages and benefits, and by laying them off when they conduct demonstrations. This issue is faced by both local and foreign expatriates.

This research further reports the lack of involvement and participation of the communities in carrying out decisionsmaking policies on tourism. The elites tend to influence the planning and policy associated with tourism through the representation of relevant stakeholders. Assuming the local people are not allowed to participate in the planning and decision-making policy, false assumptions are made regarding issues of human rights defenders, and unsustainable practices are expected to emerge.

\section{CONCLUSION}

In conclusion, this research analyzes the tourism approach utilized by government for sustainability. It also tends to eliminate the pessimistic observation which stated that tourism does not only spawn a golden egg, rather it also destroys its own nest' does not apply to the case of tourist development in Karimunjawa village. With past and current tourism planning and policy models, inadequate attention is given to HRDs as the major contributors to its sustainability. The maintenance of tourism in local communities minimizes negative socio-cultural impacts to some extent, however, the involvement of expatriate and foreign ownership employees brings about the issue of socio-economic sustainability in the industry.

For tourism to be sustainably developed, the host community needs to feel its benefits. This research shows that ad hoc government policies in accordance with human rights enforcement have a negative impact on prolonged sustainability. Undeniably, instead of undertaking the required ad hoc skills development program, a visionary long-term tourism-related HR policy needs to be implemented. This requires an effective HRD policy that is focused on investing in the local communities by creating an educated and skilled workforce, improving its quality and in developing professional tourism educators. Furthermore, government creates skilled and educated initiatives for local residents with managerial and supervisory positions.

\section{ACKNOWLEDGMENT}

Th authors are grateful to the Ministry of Research, Technology, and Higher Education, the Republic of Indonesia for funding this research. 
Management 32(2):367-376.

DOI: $10.1016 /$ j.tourman.2010.03.006.

[14] Baum, T. and Szivas, E. (2008). HRD in Tourism: A Role for Government? Tourism Management 29(4): 783-794.

[15] Baum, T. (2006). Human Resource Issues. In Baldacchino, G. (Ed) Extreme Tourism: Lessons From the World's Cold Water Islands. Amsterdam. Elsevier: $41-49$

[16] Kusluvan, S., Kusluvan, Z., Ilhan, I., and Buyruk, L. (2010). The Human Dimension: A Review of Human Resources Management Issues in the Tourism and Hospitality Industry. Cornell Hospitality Quarterly 51(2): 171-214.

Blanco, A., (2004). Rural tourism in Spain: an analysis of recent evolution. Geoforum 35 (6), 755-769.

[5] MacDonald, R., Jolliffe, L., (2003). Cultural rural tourism: evidence from Canada. Annals of Tourism Research 30, pp. 307-322..

[6] Briedenhann, J., Wickens, E., (2004). Tourism routes as a tool for the economic development of rural areas - vibrant hope or impossible dream? Tourism Management 25, 71-79.

[7] Hall, D., (2004). Rural tourism development in South-Eastern Europe: transition and the search for sustainability. International Journal of Tourism Research 6, 165-176.

[8] Ryan, C. (2001). Tourism in the South Pacific - A Case of Marginalities. Tourism Recreation Research 26(3): 43-49.

[9] Hawkins, E. (1982). Social and Economic Impact of Tourism on Asian Pacific Region. Tokyo: Asian Productivity Organization, Japan..

[10] Kusluvan, S., Kusluvan, Z., Ilhan, I., and Buyruk, L. (2010). The Human Dimension: A Review of Human Resources Management Issues in the Tourism and Hospitality Industry. Cornell Hospitality Quarterly 51(2): 171-214.

[11] Liu, A. and Wall, G. (2006). Planning Tourism Employment: A Developing Country Perspective. Tourism Management 27(1): 159-170.

[12] Barney, J. and Clark, D. (2007). Resource-based Theory: Creating and Sustaining Competitive Advantage. Oxford. Oxford University Press.

[13] Wong, E., Mistilis, N. and Dwyer, L. (2011). A framework for analyzing intergovernmental collaboration - The case of ASEAN tourism Tourism
[17] Cooper, C., Fletcher, J., Fyall, A., Gilbert, D. and Wanhill, S. (2008). Tourism: Principles and Practice (4th Edition). Essex. Pearson Education Ltd..

[18] Campos-Soria, J., Gonzalez, G. and Ropero, A. (2005). Service Quality and Competitiveness in the Hospitality Sector. Tourism Economics 11(1): 85-102.

[19] UNWTO (2004). Indicators of Sustainable Development for Tourism Destinations: A Guidebook. Madrid. UNWTO

[20] Lewis, A. (2006). Stakeholder Informed Tourism Education: Voices from the Caribbean. Journal of Hospitality, Leisure, Sport \& Tourism Education 5(2): 14-24.

[21] Baum, T. (2006). Human Resource Issues. In Baldacchino, G. (Ed) Extreme Tourism: Lessons From the World's Cold Water Islands. Amsterdam. Elsevier: 41-49.

[22] Naama, A., Haven-Tang, C., \& Jones, E. (2008). Human resource development issues for the hotel sector in Libya: a government perspective. International Journal of Tourism Research, 10(5), 481492. doi: $10.1002 /$ jtr.683

[23] Esichaikul, R. \& Baum T., 1998. The case for government involvement in human resource development: A research of the Thai hotel industry, Tourism Management, Volume 19, Issue 4, August 1998, Pages 359-370

[24] McLean, N. (2004). National Human Resource Development: What in the World Is It? Advances in Developing Human Resources 6(3): 269-275. 
[29] Cooper, C., Fletcher, J., Fyall, A., Gilbert, D. and Wanhill, S. (2008). Tourism: Principles and Practice (4th Edition). Essex. Pearson Education Ltd.

[30] Baum, T. and Szivas, E. (2008). HRD in Tourism: A Role for Government? Tourism Management 29(4): 783-794.

[31] Krippendorff, K. 2004. Reliability in Content Analysis. Human Communication Research. Volume30, Issue3, Pages 411-433.

[32] Kamberilis, G. \& Dimiatridis. 2005. On Qualitative Inquiry. New York. Columbia University, Teachers College Press.
(2011). A Framework for Analyzing Intergovernmental Collaboration - The Case of ASEAN Tourism. Tourism Management 32(2): 367-376. 